\title{
Solid Oxide Fuel Cells coupled with a biomass gasification unit
}

\author{
Marek Skrzypkiewicz ${ }^{1, a}$, Michał Wierzbicki ${ }^{1}$ and Michał Stępieńn ${ }^{1}$ \\ ${ }^{1}$ Institute of Power Engineering, Thermal Processes Department, Ul. Augustówka 36, 02-981 Warsaw, Poland
}

\begin{abstract}
A possibility of fuelling a solid oxide fuel cell stack (SOFC) with biomass fuels can be realized by coupling a SOFC system with a self-standing gasification unit. Such a solution enables multi-fuel operation, elasticity of the system as well as the increase of the efficiency of small-scale biomass-to-electricity conversion units. A system of this type, consisting of biomass gasification unit, gas purification unit, SOFC stack, anode off-gas afterburner and peripherals was constructed and operated successfully. During the process, biomass fuel (wood chips) was gasified with air as gasification agent. The gasifier was capable of converting up to $30 \mathrm{~kW}$ of fuel to syngas with efficiencies up to $75 \%$. Syngas leaving the gasification unit is delivered to a medium temperature adsorber for sulphur compounds removal. Steam is added to the purified fuel to maintain steam to carbon ratio higher than 2 . The syngas then is passed to a SOFC stack through a fuel preheater. In such a configuration it was possible to operate a commercial $1.3 \mathrm{~kW}$ stack within its working regime. Conducted tests confirmed successful operation of a SOFC stack fuelled by biomass-sourced syngas.
\end{abstract}

\section{Introduction}

Biomass gasification coupled with solid oxide fuel cells (highly efficient power generation technology) gives the opportunity to increase the amount of electricity generated from biomass in overall power generation. The use of renewable fuels such as biomass is justified from the environmental point of view as well as to ensure the energy resources availability. The disaster at the Fukushima nuclear power plant in Japan has resulted in reduction plans for nuclear power in several countries. On the other hand, the increase of power generation from renewable energy sources (wind, solar) has already faced some barriers associated with the balance of electricity demands and supply which cause needs for large amounts of energy storage. This problem has not been solved yet, despite of extensive research. Production of electricity from biomass, due to the continuity of the generation process is not subjected to these constraints.

Fuel cell technology can be used as a stand-alone system or integrated with complementary technology for electricity generation (organic Rankine cycle - ORC, gas turbine (GT) or recuperative micro gas turbine - MGT). Because of the typical for fuel cell separation of the exhaust gases (on the anode side residual fuel gas, on the cathode side depleted air), it is possible to use the residual fuel for the additional electric power generation (e.g. in a gas turbine) [1]. Alternatively, through the burning of residual fuel, it is possible to generate additional heat for the purpose of:

a) thermal integration,

b) production of domestic hot water, c) additional electricity generation (ORC, Stirling engine).

Direct use of conventional technologies (internal combustion engine) and Stirling engine for the generation of electricity from biomass has been considered in small scale CHP systems [2]. These solutions have relatively small electrical efficiency [3]. For example, a Danish company DK Sterling offers a $140 \mathrm{~kW}$ system operating on wood chips with electrical efficiency of $17 \%$ [4]. However, the Stirling engine technology is promising in the case of availability of waste heat in the system.

The integrated power generation system based on gasification reactor and solid oxide fuel cell is considered to be one of the promising technologies [5]. Generation of fuel for SOFC can be performed in gasification reactor with a use of number of gasifying agents: a mixture of steam and air, mixtures of oxygen, carbon dioxide and water vapour, as well as pure carbon dioxide (Boudouard reaction).

The results presented in this paper concentrate mainly on generation of electricity in SOFC stack fed with fuel gas produced in a fixed bed, counter - current biomass gasification reactor with a use of air as a primary gasifying agent.

Micro-CHP systems based on solid oxide fuel cells technology offer the highest fuel-to-electricity conversion efficiency (up to $60 \%$ ), when compared to systems based on internal combustion engines (ICE), and Stirling engines (both ca. 20\%) [6,7]. They are dedicated for continuous operation and the excess of electrical energy can be supplied to the grid.

\footnotetext{
a Corresponding author: marek.skrzypkiewicz@ien.com.pl
} 
An important aspect for the implementation of the micro-CHP/SOFC systems fed by fuel from biomass gasification is the cleaning process of the fuel stream. It is necessary to limit the content of pollutants which may cause performance drop or anode degradation to the level accepted by fuel cells.

Research in the field of purification of gasification products led to the development and implementation of effective method of low temperature gas cleaning for SOFC.

\section{SOFC systems fed with syngas from biomass gasification - state of the art}

Thorough analysis of the biomass gasification reactor (air as gasifying agent) coupled with a 1-2 kW SOFC system has recently been carried out. Analysis takes into account the moisture content in the biomass feedstock [8]. Appropriate integration of the systems enables increase of the electrical efficiency from $24.7 \%$ to $37.7 \%$. The increase of the electrical efficiency is directly related to the fuel utilization factor in the fuel cell module. Optimisation analysis of the system fuelled by wet biomass and using air as a gasifying agent indicates that the ratio of water to biomass (STBR) of 1.5 leads to the highest efficiency with a minimum amount of fuel cells [10]. The SOFC fuel utilization at $75 \%$ leads to the highest system efficiency. Additionally, partial anode gas recirculation has been analysed. The optimum level of residual fuel recirculation from the anode side has been optimised at $60 \%$ [9]. A method of gas cleaning process has an important effect on the efficiency of integrated gasification-SOFC system. Fuel purification is necessary due to the purity requirements of the solid oxide fuel cells. Comparison of two possible scenarios of syngas treatment leads to the conclusion that the hightemperature cleaning allows higher thermal efficiency compared to the low temperature cleaning [10]. Due to the higher cost of high-temperature cleaning, the decisive economic element is the income from the sale of the thermal energy generated in the system.

Carbon deposition in SOFC stack is an important problem for development of SOFC based systems, fuelled by syngas from biomass gasification. It is a result of the thermodynamics and kinetics processes on the anode surface in the presence of syngas. The processes of carbon deposition were the subject of a number of experimental and thermodynamic analyses [1].

Carbon deposition on the surface of the anode side of SOFC decreases with increase of water vapour content in the fuel. Increasing the content of water vapour in the feed gas can be realized by:

a) increase of the steam addition (gasifying agent) during the gasification of biomass,

b) additional steam addition to the stream of fuel gas before the SOFC stack.

Carbon deposition on the anode of SOFC is also influenced by the current load. The process has smaller effect when the current load increases. There is a limit value of the current above which the carbon deposition does not occur. This is an effect of direct carbon oxidation on the anode surface by oxygen ions $\mathrm{O}^{2-}$, which activity increases with current load [11]. However, the deposition of carbon may occur on other elements of the stack and block the access for the reactant gases to the surface of the anode.

High tar content in the fuel is a significant factor affecting and intensifying carbon deposition processes. Tars influence on the cell degradation is often determined by experimental test with the use of representative composition of the tar (naphthalene, benzene, and toluene). However, in reality, degradation is much lower in the presence of real tars then for example in the presence of the toluene [12].

\section{Experimental investigations of SOFC stack}

The tests of a SOFC stack coupled with biomass gasification reactor (Figure 1) have been conducted in laboratory of the Institute of Power Engineering (IEn). The test stand is divided in several sections:

a) fuel supply and conditioning (peristaltic pump, gas flow controllers, electric gas heaters, steam generator, heat exchangers),

b) the air supply (air flow controller, electric heater),

c) fuel cell section (SOFC stack, impedance spectrometer FuelCon, current and voltage connections),

d) residual fuel utilization (fuel afterburner, cooler, a set of gas analysers, ventilation),

e) data acquisition and control system.

The section of fuel supply and conditioning was responsible for preparation of fuel for testing purposes. Fuel was pre-heated to a temperature of $300^{\circ} \mathrm{C}$ and humidified by the addition of steam from the steam generator. The humidified fuel is then delivered to the primary heater, which provided adequate inlet temperature of the fuel before the fuel cell stack (approx. $800^{\circ} \mathrm{C}$ ). In the first phase of testing the reference gases were supplied from gas cylinders with a use of mass flow controllers.

Next, when the fuel was delivered from biomass gasification reactor with a use of peristaltic pump, the flows of reference gases (from gas cylinders) through the mass flow controllers were gradually reduced to zero.

The air supply section besides main goal of providing the oxidant to the electrochemical reaction in fuel cells allows the temperature control inside the stack by controlling the flow rate and air inlet temperature. Air flows were regulated in such a way to ensure the oxidant utilization below $30 \%$.

The electrochemical tests of SOFC stack integrated with gasification reactor were conducted with a use of the impedance spectrometer FuelCon with electronic load. Measuring apparatus allowed control of current load and voltage readout in the several sections of the fuel cell stack. In the first stage of the tests the analysis of fuel cell performance at different current loads was conducted. Next during long term stability tests the current was kept at constant value of $18 \mathrm{~A}$. 
The analysis of SOFC stack performance during operation on fuel from biomass gasification reactor included the following tests:

a) Performance monitoring (at different current loads) of the fuel cell stack before and after the long term test at reference fuel $\left(\mathrm{H}_{2}, \mathrm{~N}_{2}\right)$ and the simulated fuel $\left(\mathrm{H}_{2}, \mathrm{CO}, \mathrm{CO}_{2}, \mathrm{CH}_{4}\right)$,

b) Performance monitoring (at different current loads) of the fuel cell stack on the fuel delivered from biomass gasification reactor $\left(\mathrm{H}_{2}, \mathrm{CO}, \mathrm{CO}_{2}, \mathrm{CH}_{4}\right)$ before and after the long term test,

c) Long term stabilization test (at constant current) of the fuel cell stack on the fuel delivered from biomass gasification reactor $\left(\mathrm{H}_{2}, \mathrm{CO}, \mathrm{CO}_{2}, \mathrm{CH}_{4}\right)$.

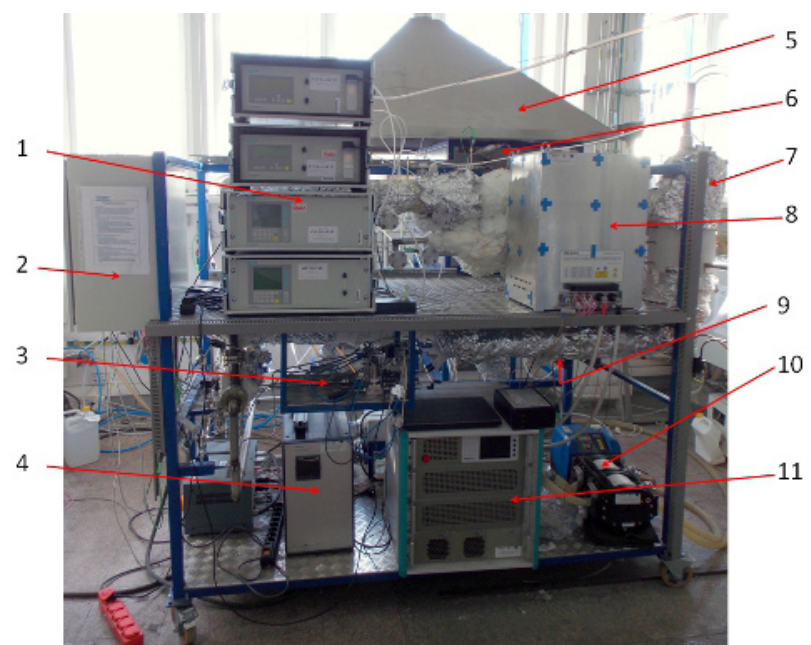

Figure 1. Experimental setup for SOFC stack testing fuelled by syngas coming from biomass gasification process: 1) Gas analysers, 2) Control box, 3) Mass flow controllers, 4) Steam generator, 5) Ventilation system, 6) Air heater, 7) Afterburner, 8) SOFC stack, 9) Fuel heater, 10) Fuel pump, 11) Electronic load.

Experimental studies of the stack consisting of 60 electrolyte supported cells have been performed based on the acquisition of current - voltage curves for fuel mixture with different chemical composition. The air flow was variable and dependent on the stack temperature.

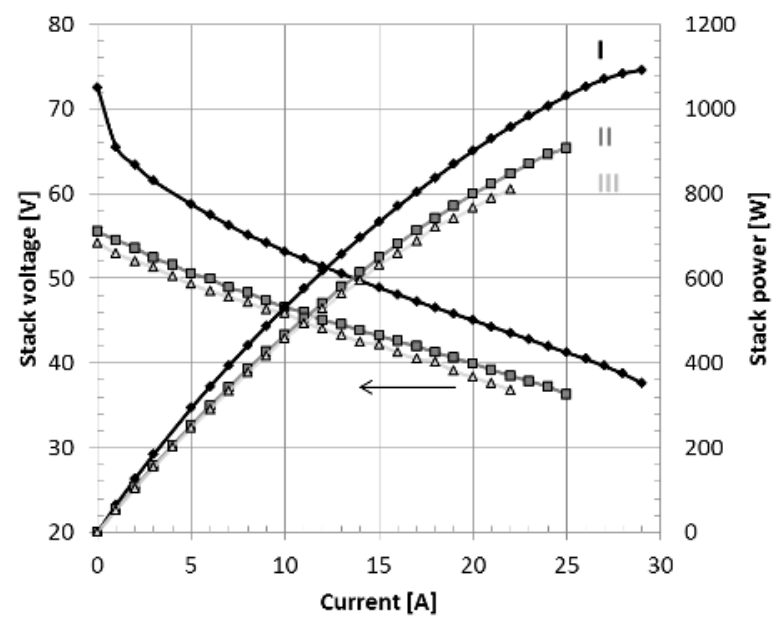

Figure 2. Current - voltage and power curves at stack temperature $850^{\circ} \mathrm{C}$ before long term test for three considered fuels
First stage of experimental campaign just before long term test using syngas from gasifier was devoted to current - voltage analysis for dry fuel reference mixture $\mathrm{H}_{2} / \mathrm{N}_{2}$ containing $40 \%$ of hydrogen (Fuel I) at flow that corresponds to $75 \%$ of fuel utilization at stack operating temperature $850^{\circ} \mathrm{C}$. The electrical power was equal $1079 \mathrm{~W}$ for electric current of $29 \mathrm{~A}$ and the stack voltage equal $37 \mathrm{~V}$.

Next experimental investigation has been performed using synthetic syngas (Fuel II) with chemical composition of $19 \% \mathrm{CO}, 10 \% \mathrm{CO}_{2}, 3 \% \mathrm{CH}_{4}, 13 \% \mathrm{H}_{2}$, and $54 \% \mathrm{~N}_{2}$. The stack performance obtained in this case is lower than in the previous case and the electric power reached $895 \mathrm{~W}$ at stack current $25 \mathrm{~A}$ and voltage of $36 \mathrm{~V}$.

Another current - voltage curve was performed for flow of real syngas obtained from the gasification of biomass (Fuel III). Chemical composition of syngas mixture delivered from gasification reactor (gasification agent: air, fuel: wood chips)was measured as $18.24 \% \mathrm{CO}$, $12.35 \% \mathrm{CO}_{2}, 2.6 \% \mathrm{CH}_{4}$, and $12.35 \% \mathrm{H}_{2}$. The electrical power of the stack for Fuel III was $788 \mathrm{~W}$ at electric current $22 \mathrm{~A}$ and stack voltage of $36 \mathrm{~V}$. The results of all performed measurements for selected fuels are shown in Fig. 2.

Table 1. Power, current and voltage values for considered fuels at stack temperature $850^{\circ} \mathrm{C}$ before long term test.

\begin{tabular}{|c|c|c|c|}
\hline Fuel & $\begin{array}{c}\text { Stack Power } \\
{[\mathrm{W}]}\end{array}$ & $\begin{array}{c}\text { Stack Current } \\
{[\mathrm{A}]}\end{array}$ & $\begin{array}{c}\text { Stack Voltage } \\
{[\mathrm{V}]}\end{array}$ \\
\hline Fuel I & 1079 & 29 & 37 \\
\hline Fuel II & 895 & 25 & 36 \\
\hline Fuel III & 788 & 22 & 36 \\
\hline
\end{tabular}

From obtained experimental results it can be concluded that the amount of hydrogen in the fuel stream has significant effects on the performance of the SOFC stack. With the increase of hydrogen content in the fuel, the performance of the stack increases. The highest power values of the stack have been obtained for a dry reference fuel mixture containing $40 \% \mathrm{H}_{2}$. However, in case of fuel from the gasification of biomass, the performance was lower by ca. $290 \mathrm{~W}$.

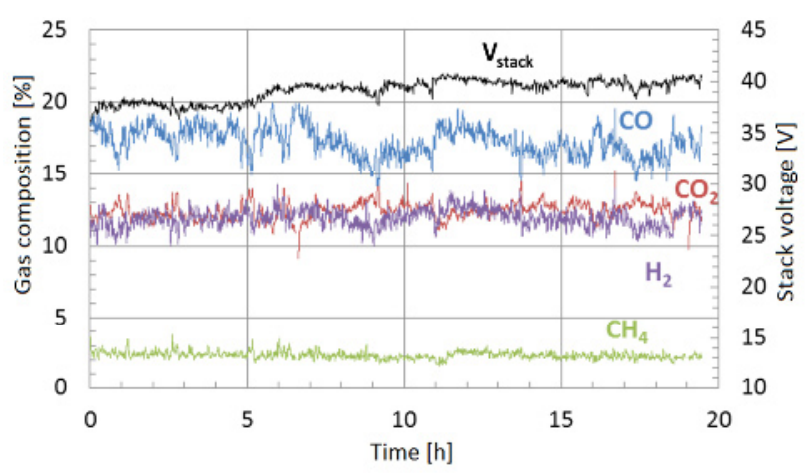

Figure 3. Stack voltage and chemical composition of produced syngas at the inlet to stack during long term test. Stack temperature $850^{\circ} \mathrm{C}$.

Another series of tests has been carried out and was related to monitoring voltage of the stack under a constant current load. Applied electric current was equal 18A. During this experiment, the composition of syngas from biomass gasification was also checked 
and recorded. The resulting stack voltage variation as a function of time and the composition of syngas from gasification is presented in Fig. 3 .

It can be observed that the voltage of the stack during the long term operation of the stack (about 20 hours) under constant current load seems to be stable and their fluctuations were estimated within range of $4 \mathrm{~V}$. Thus, it can be concluded that tightness of the tested system was good and the chemical composition of fuel mixture delivered from biomass gasification was stable.

In turn, Figure 4 shows the exhaust gas from the stack during realization of a long term test under constant current load. It can be clearly seen that concentration of hydrogen and carbon monoxide is much lower than for the composition of the inlet fuel mixture. This is due to consumption of these components as the result of electrochemical reaction. In addition the higher concentration of carbon dioxide can be observed which is caused by formation of carbon dioxide during "water shift" process.

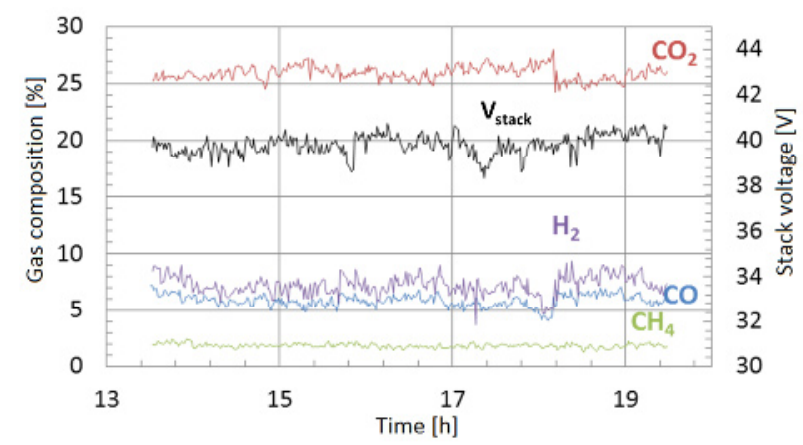

Figure 4. Stack voltage and chemical composition of produced syngas at the inlet to stack after long term test. Stack temperature $850^{\circ} \mathrm{C}$.

The next stage of the experimental work was related to perform and analysis of polarization curves after the long term test carried out using syngas coming from gasification process. Four current - voltage characteristics has been recorded for different fuel chemical compositions. Similarly to the first stage of experimental investigation, the highest stack electric power was obtained for the dry reference fuel mixture $\mathrm{H}_{2} / \mathrm{N}_{2}$ (Fuel I) at current $27 \mathrm{~A}$ and stack voltage equal $40 \mathrm{~V}$. The output power of the stack was about $1095 \mathrm{~W}$. It should be noted that the resulting stack performance is very similar to those which have been obtained just before start of long term test. This demonstrates the good quality of the tested system including purity of the fuel without presence of any degradation processes [13].

Next current-voltage curves for reference fuel mixture $\mathrm{H}_{2} / \mathrm{N}_{2}$ humidified with water vapour (Fuel IV) has been recorded. For such a fuel composition the stack performance characterized by electric power was equal $955 \mathrm{~W}$ at electric current $26 \mathrm{~A}$ and stack voltage of $37 \mathrm{~V}$. Another current - voltage characteristics was performed for synthetic syngas (Fuel II) and syngas (Fuel III) obtained directly from the gasification of biomass. The results of performance of the stack were comparable to each other and were equal to $854 \mathrm{~W}$ and $832 \mathrm{~W}$ respectively.
During measurements of these current - voltage curves the stack temperature was maintained at the level of about $850^{\circ} \mathrm{C}$. The above described polarization curves were presented in Fig. 5.

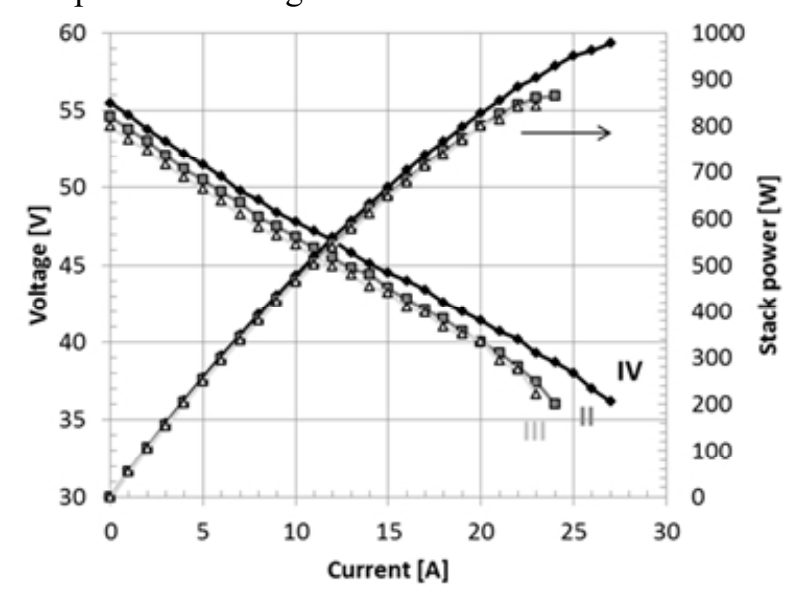

Figure 5. Current - voltage and power curves at stack temperature $850^{\circ} \mathrm{C}$ after long term test for considered fuels

All more relevant results of the whole experiment has been collected and presented in Table 2 .

Table 2. Power, current and voltage values for considered fuels at stack temperature $850^{\circ} \mathrm{C}$ after long term test.

\begin{tabular}{|c|c|c|c|}
\hline Fuel & $\begin{array}{c}\text { Stack Power } \\
{[\mathrm{W}]}\end{array}$ & $\begin{array}{c}\text { Stack Current } \\
{[\mathrm{A}]}\end{array}$ & $\begin{array}{c}\text { Stack Voltage } \\
{[\mathrm{V}]}\end{array}$ \\
\hline Fuel I & 1095 & 27 & 40 \\
\hline Fuel II & 854 & 24 & 36 \\
\hline Fuel III & 832 & 22 & 38 \\
\hline Fuel IV & 955 & 26 & 37 \\
\hline
\end{tabular}

\section{Summary}

Possibility of fuelling the SOFC fuel cell stack with fuel coming from biomass gasification process makes the electricity generation system based on gasification reactor one of the promising technologies. Such solutions can be competitive in distributed power generation systems (less than $1 \mathrm{MW}$ ). However, firstly it is necessary to prepare gaseous fuel in the gasification reactor and also some amount of steam in order to prevent carbon deposition. In addition, very important issue is the effective gas cleaning system for pollutants removal that cause decreasing of performance or degradation of the material components of the stack.

The performed study of fuel cell stack allowed for a detailed analysis of operating conditions concerning fuelling with syngas coming from biomass gasification reactor.

The current-voltage characteristics and power curves of SOFC stack fuelled with the reference fuel, synthetic syngas and the real syngas coming from gasification of biomass has been performed. These characteristics were recorded both before and after the long term test. Analysis of the results shows that the highest stack power of $1.1 \mathrm{~kW}$ has been reached for the reference fuel. However, in the case of synthetic syngas and the syngas obtained from the gasification process electric power of the stack is lower than for reference fuel about $250 \mathrm{~W}$. It was observed that operating parameters on synthetic 
syngas are very close to parameters for real syngas obtained directly from biomass gasification process. It shows good tolerance of cells in the SOFC stack to a small amount of impurities in the fuel.

Long term tests were carried out for stack fuelled with syngas obtained from the gasification process under a constant current load. Operation of SOFC stack was stable during whole test. Operating voltage of the stack within 20 hours was nearly constant and equal about $39 \mathrm{~V}$.

Performed experimental studies confirmed the possibility of fuelling SOFC based systems with purified syngas, together with maintaining high operation performance of the fuel cell stack. As a result, the experimental data has been obtained, which have been used to verify the design and modelling calculations $[14,15]$. In addition, the experimental results will be used for further work aimed to developing technology of cogeneration systems, including micro - CHP systems based on SOFC stacks [16]. The cleaned fuel coming from biomass gasification process is considered as one of the most promising fuels for similar systems for combined production of electricity and heat.

\section{Acknowledgements}

The work was done within the National key project of the Polish Ministry of Science and Higher Education (POIG.01.01.02-00-016/08).

\section{References}

1. C. Athanasiou, F. Coutelieris, E. Vakouftsi, V. Skoulou, E. Antonakou, G. Marnellos, A. Zabaniotou, Int. J. Hydrogen Energ. 32, 337-342 (2007)

2. Y. Huang, D.R. McIlveen-Wright, S. Rezvani, M.J. Huang, Y.D. Wang, A.P. Roskilly, N.J. Hewitt, Appl. Energ. 112, 518-525 (2013)

3. L. Dong, H. Liu, S. Riffat, Appl. Therm. Eng. 29, 2119-2126 (2009)

4. Gasification in Stirling Engine Applications, Stirling DK marketing materials, October 2010.

5. C.O. Colpan, F. Hamdullahpur, I. Dincer, Y. Yoo, Int. J. Hydrogen Energ. 35, 5001 - 5009 (2010)

6. J. Jewulski, J. Kupecki, M. Błesznowski, Instal 1, 11-15 (2014)

7. E. Podesser, Renew. Energ. 16, 1049-1052 (1999)

8. G. Campitelli, S. Cordiner, M. Gautam, A. Mariani, V. Mulone, Int. J. Hydrogen Energ. 38, 320-327 (2013)

9. S. Wongchanapai, H. Iwai, M. Saito, H. Yoshida, J. Power Sources 216, 314-322 (2012)

10. A.O. Omosun, A. Bauen, N.P. Brandon, C.S. Adjiman, D. Hart, J. Power Sources 131, 96-106 (2004)

11. I.V. Yentekakis, J. Power Sources 160, 422-425 (2006)

12. E. Lorente, M. Millan, N.P. Brandon, Int. J. Hydrogen Energ. 37, 7271-7278 (2012)

13. M. Błesznowski, J. Jewulski, A. Zieleniak, Centr. Eur. J. Chem. 11, 960-967 (2013)
14. J. Kupecki, K. Motylinski, M. Ferraro, F. Sergi, N. Zanon, Journal of Power Technologies 96, 63-71 (2016)

15. J. Kupecki, J. Milewski, A. Szczesniak, R. Bernat, K. Motylinski, Int. J. Hydrogen Energ. 40, 1583415844 (2015)

16. S. Sieniutycz, M. Błesznowski, A. Zieleniak, J. Jewulski, Int. J. Heat Mass Tran. 15-16, 3984-3994 (2012) 